\title{
What drives cross-border M\&As in commercial banking?
}

\author{
Mohamed Azzim Gulamhussen ${ }^{\mathrm{a}}$, Jean-François Hennart ${ }^{\mathrm{b}, *}$, Carlos Manuel Pinheiro ${ }^{\mathrm{c}}$ \\ a ISCTE-IUL Business School; Vlerick Business School \\ ${ }^{\mathrm{b}}$ Tilburg University, Heuvelstraat 14, 5131AP Alphen, The Netherlands

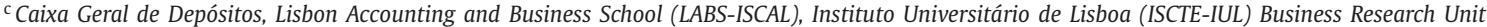 \\ (BRU-IUL), Lisboa, Portugal
}

\section{A R T I C L E I N F O}

\section{Article history:}

Received 30 September 2014

Accepted 6 July 2016

Available online 22 July 2016

\section{JEL classification:}

F21

F21

G21

G34

Keywords:

International banking

Market entry

Banks

Mergers and acquisitions

\begin{abstract}
A B S T R A C T
Using a gravity model, we analyze the determinants of the probability that commercial banks in 89 acquiring countries and 118 target countries will undertake M\&As over a 30-year period (1981-2010) and of the value of these M\&As. We find that the value of cross-border M\&As increases with the size of the acquiring country, and that both the probability and value of M\&As vary positively with the depth of the financial market in acquirer countries and the presence of corporate and non-corporate customers from acquiring countries in target countries, and negatively with the geographic, psychic, and time zone distances between acquirer and target countries. Our study highlights the role of non-corporate customers and of psychic distance in the cross-border expansion of commercial banks through M\&As.
\end{abstract}

(c) 2016 Elsevier B.V. All rights reserved.

\section{Introduction}

Which country-level factors lead banks to engage in crossborder M\&As? This question is gaining significant attention from researchers (see, among others, Buch and DeLong, 2004; Focarelli and Pozzolo, 2001, 2008, and Buch and Lipponer, 2007 as well as Amel et al., 2004; Buch and DeLong, 2008, and DeYoung et al., 2009 for surveys). Their findings show that trade, a proxy for the follow-the-corporate-customer motive (Focarelli and Pozzolo, 2001), geographic and cultural distances between acquirer and target countries (Buch and DeLong, 2004; Buch et al., 2014), and country characteristics such as the market sizes of acquirer and target countries (Focarelli and Pozzolo, 2008), lead banks to undertake cross-border M\&As. ${ }^{1}$ Still, "little is known why foreign

\footnotetext{
* Corresponding author. Fax: +31 134662875.

E-mail addresses: magn@iscte.pt, azzim.gulamhussen@vlerick.com (M.A. Gulamhussen), j.f.hennart@uvt.nl (J.-F. Hennart), carlos.manuel.pinheiro@cgd.pt (C.M. Pinheiro).

1 The literature on M\&A activity is vast. One strand looks at firm-level factors that lead banks to engage in M\&A. These studies often control for acquirer and host country factors. A major criticism to these studies is the difficulty to disentangle bank and country-level factors that lead to M\&A activity, since they include two sources of heterogeneity, country and bank, in the same specification (e.g. Berger et al., 1999; Buch et al., 2013). Berger at al. (1999) is one the few studies that looks at the choice between M\&A and greenfield entry. Another strand of studies looks
}

banks enter some markets and not others, and how this relates to home and host country factors, including bilateral aspects" (Claessens and Van Horen, 2014a: 317).

Figs. 1 and 2 track cross-border M\&As between 89 acquiring and 118 target countries since the 1980s. Fig. 1 shows a steady increase in the number of deals while Fig. 2, which tracks their value, shows two merger waves in 1999-2001 and 2004-2008. Figs. 3 and 4 show that acquiring countries are also target countries for cross-border M\&As, i.e. if banks from country i merge with or acquire banks in country $\mathrm{j}$, then it is likely that banks from country $\mathrm{j}$ will also merge with or acquire banks in country $\mathrm{i}$. This calls for the construction of country pairs over a wide time span to study how the features of such pairs attract and deter crossborder M\&A. By focusing on country pairs, we avoid the potential confounding effects of simultaneously entering bank, country, and bilateral characteristics, as has been done in previous studies.

at the efficiency gains from M\&A activity (e.g. DeLong, 2001, 2003; Cornett et al., 2003; Cornett et al., 2006; Correa, 2009). Again a major criticism to these studies is the difficulty to disentangle the stock market reaction to M\&A activity and other firm and market-level factors. Along a similar line of reasoning, some studies look at the implications of $\mathrm{M} \& A s$ for lending, more often to small and medium enterprises (e.g. Garmaise and Moskowitz, 2006; Craig and Hardee, 2007; Panetta et al., 2009), for deposit rates (Craig and Dinger, 2009) or for both lending and deposit (Park and Pennacchi, 2009). 


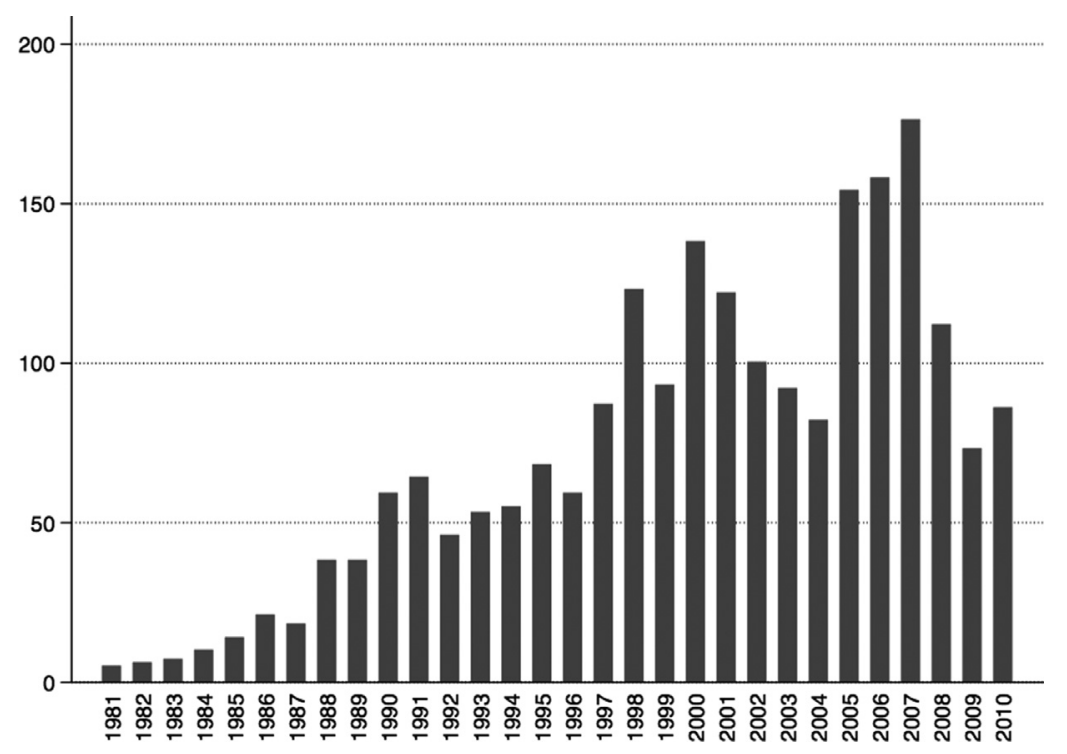

Fig. 1. Number of cross-border deals per year.

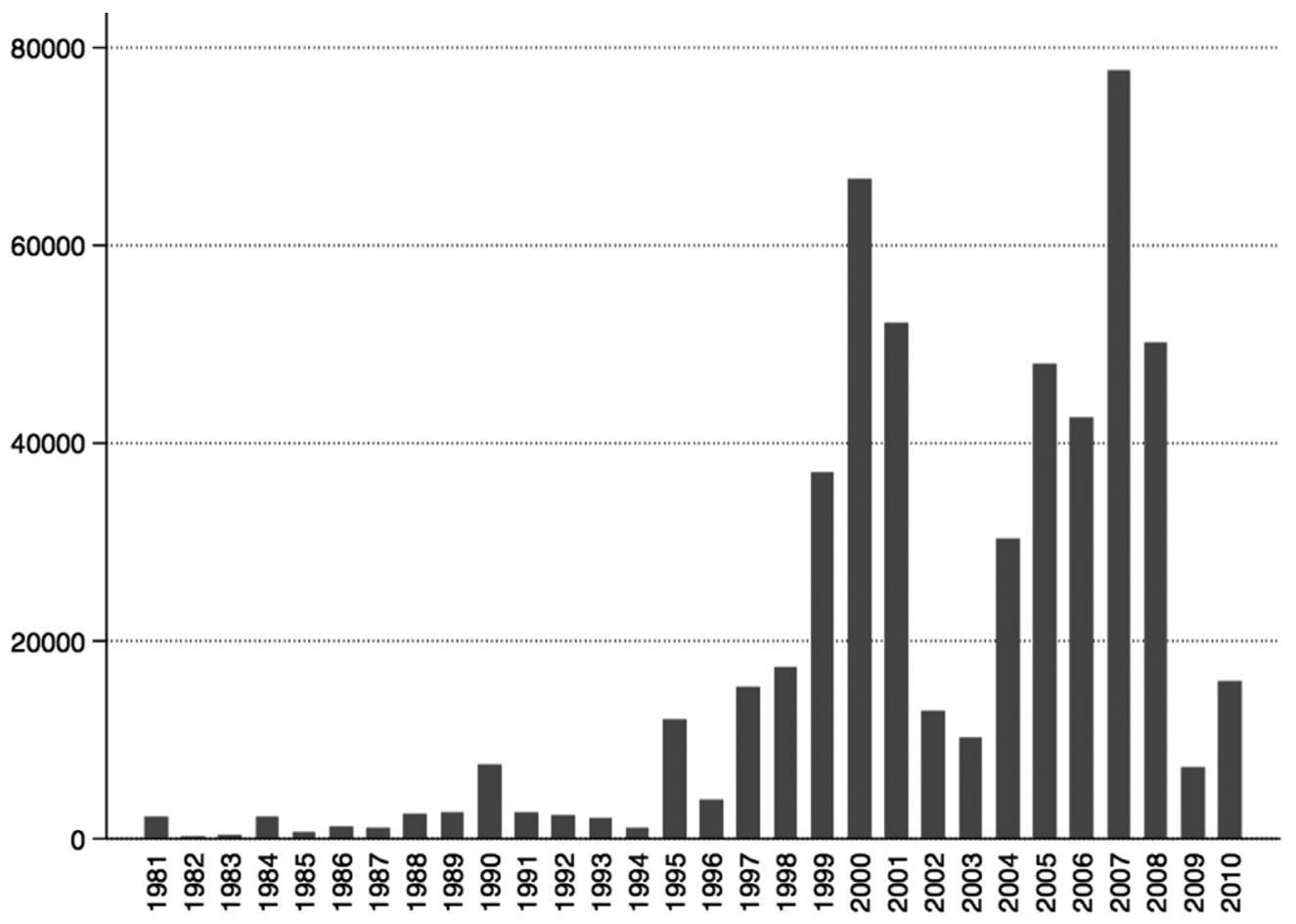

Fig. 2. Volume of cross-border deals per year (million USD).

Our study makes a number of contributions. First, we use a gravity model to explain cross-border M\&As between pairs of countries. Gravity models have been used in similar settings, for example to explain the level of credit to firms in country i provided by banks from country j and vice versa (Brüggemann, 2012) and the number and level of assets held by banks of country $i$ in country $\mathrm{j}$ and vice versa (Buch et al., 2013; Claessens and Van Horen, 2014b). Okawa and van Wincoop (2012) developed the theoretical foundations for the application of the gravity framework to cross-border financial holdings. We follow this novel literature and apply this framework to analyze country pairs involved in crossborder M\&As over the past 30 years. Second, to the best of our knowledge, we are the first to consider the role of non-corporate customers and psychic distance on the cross-border expansion of commercial banks through M\&As and to include comprehensive measures of these pulling factors or economic masses in the gravity framework. Our findings on the negative influence of geographical distance on cross-border M\&As, and on the positive one of the level of banking development in the acquirer country, are consistent with previous studies. Like them we also find that bilateral trade, as a proxy for follow-the-corporate-customer motives, has a positive effect on the number and value of cross-border M\&As. To the best of our knowledge, we are the first to hypothesize and find that the larger the number of home country migrants into a tar- 


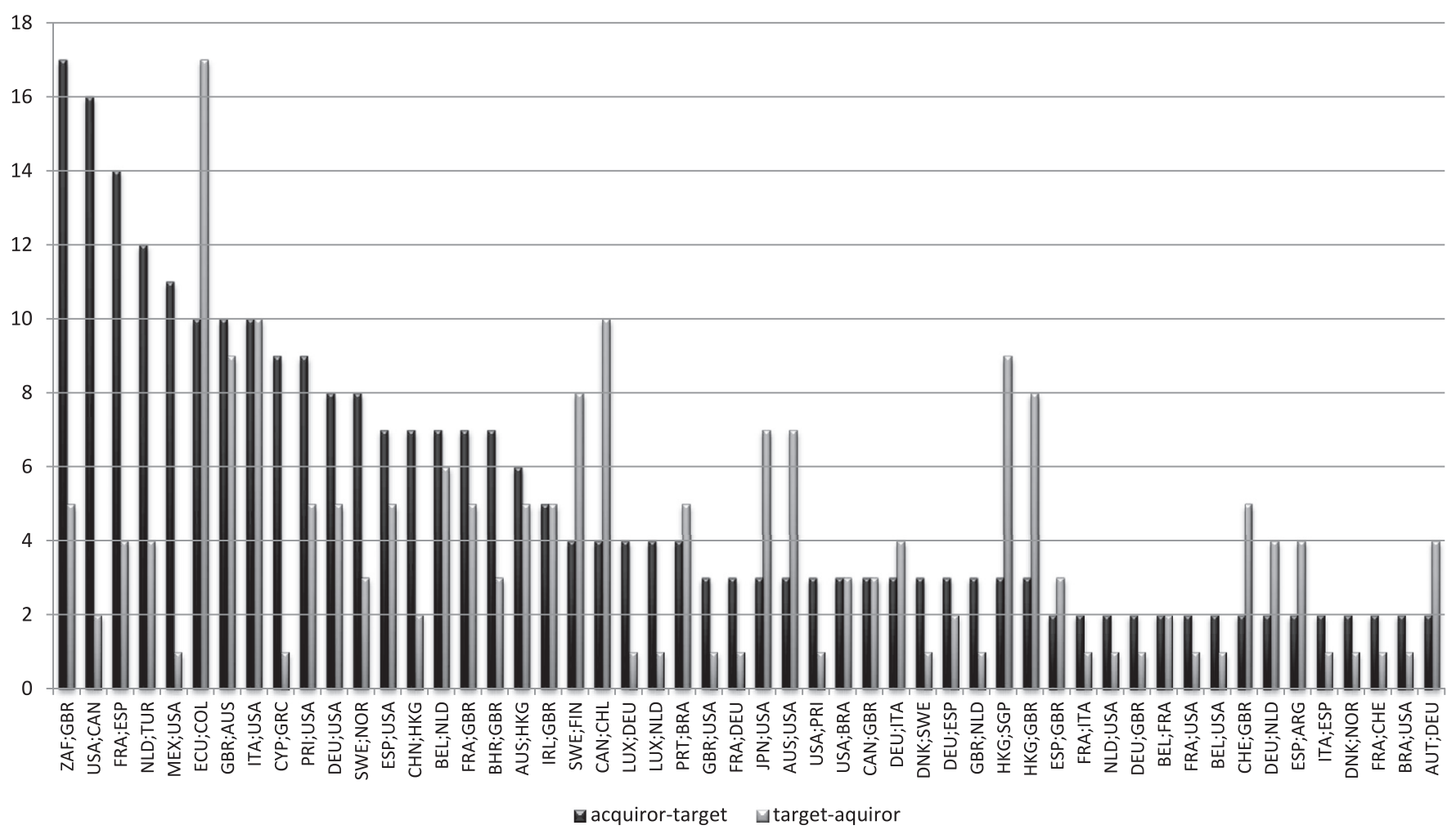

Fig. 3. Number of deals per country pair.

Note: for readability, only country pairs with more than one deal are represented.

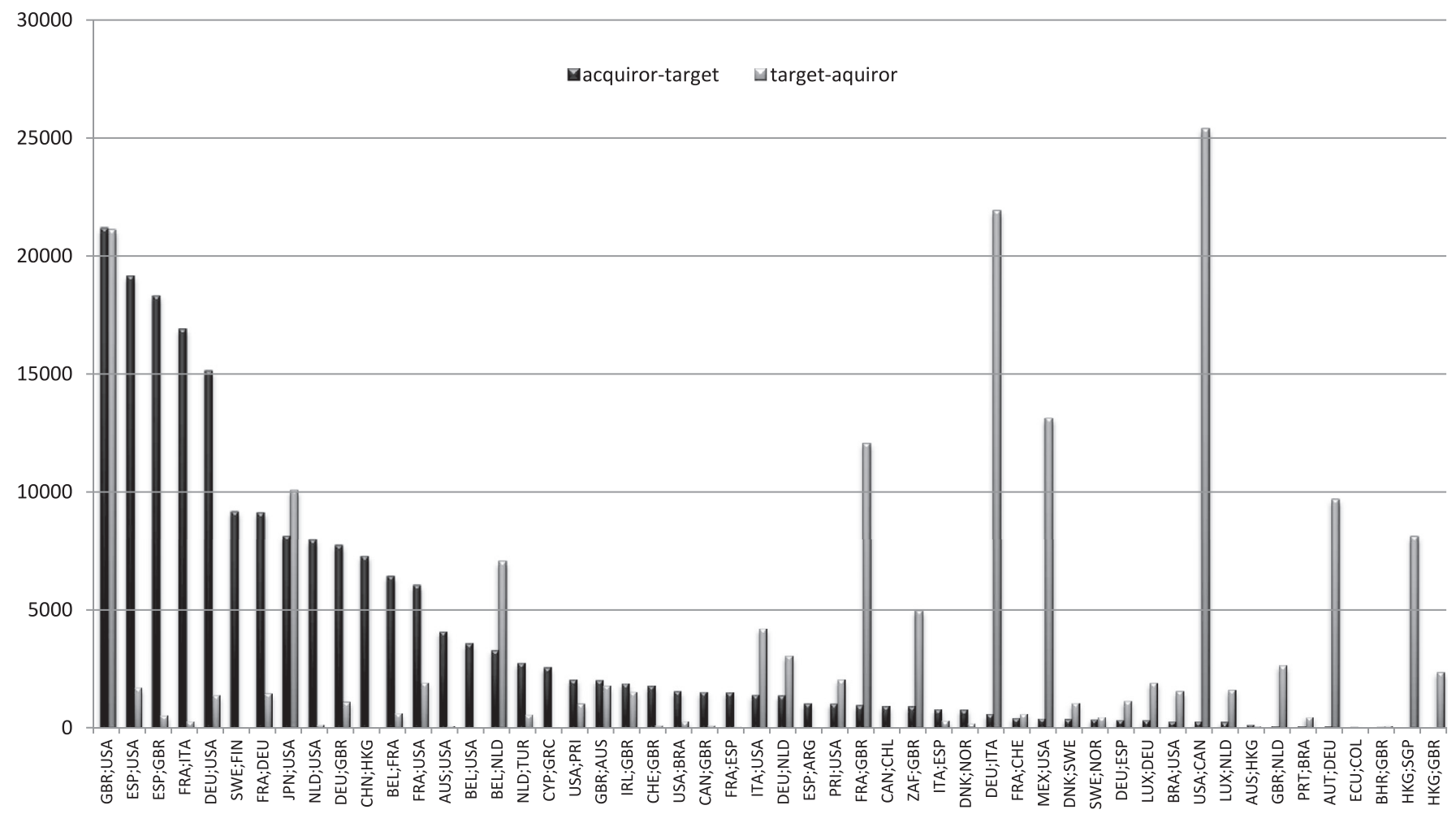

Fig. 4. Volume of deals (million USD) per country pair. 
get country, the more likely that home country banks will acquire and merge with banks in that target country. Lastly, we are also the first, as far as we know, to enter a comprehensive measure of psychic distance, a proxy for religious, linguistic and other differences between acquirer and target countries, as an explanation of cross-border M\&As. Zhu and Yang (2008) have argued that psychic distance has been rarely used in financial studies, although it features in a large number of studies on firm internationalization (Grady and Lane, 1996).

We start by reviewing the motives for cross-border M\&As. In Section 3 we describe our data, methods and variables. We present our findings in Section 4, and our conclusions in Section 5.

\section{Motives for cross-border M\&AS in banking}

Results of past studies indicate that both acquirer and target country characteristics lead banks to undertake M\&As. A distinctive feature of our study is that acquirer countries are also target countries. This feature of our data allows us to look at country pairs, which in turn makes the gravity framework most appropriate.

Gravity models are a convenient and succinct way to model all the factors that both push banks towards, and restrain them from, cross-border M\&As. Gravity models have been successfully used to explain international trade and investment flows (Tinbergen, 1962; Leamer and Levinsohn, 1995; Okawa and van Wincoop, 2012). The law of gravity states that the attraction between two objects is proportional to their mass and inversely proportional to their distance. By analogy, economic transactions between two countries, for example the number and volume of M\&As by banks in country $\mathrm{i}$ with banks in country $\mathrm{j}$, should depend on (i) the characteristics of the acquiring country, such as its size and level of development; (ii) business opportunities in the target country, and (ii) the costs of overcoming the frictions between the acquiring and the target country. Distance, whether geographic or psychic, generates costs of managing remote activities that lower their profitability and hence reduce M\&A activity. Regulatory barriers imposed by target countries on the entry of foreign banks should also reduce M\&A flows.

M\&As are a very common form through which banks based in a country expand into another (Buch and DeLong, 2004). There are a number of potential reasons why banks may want to merge with or acquire banks based in foreign countries. The first motive is common to manufacturing and other service firms expanding abroad. In the course of their business, firms accumulate some intangibles, such as new products and processes. These intangibles are often public goods, insofar as they can be used in one additional country without diminishing the amount available in all other countries where they are already in use. This makes it potentially profitable to exploit those intangibles in other countries. This is the rationale used to explain why research-and-development intensive manufacturing firms have expanded abroad (Hennart, 1982). In banking, experience with advanced back-office procedures, the development of new products and business models, and new commercialization and distribution technologies are intangibles that can be transferred from one country to another (Williams, 1997). Spanish banks, for example, have introduced new products (such as lottery-linked deposit accounts) in their South American subsidiaries, and new distribution methods, such as mini-branches in gasoline stations, supermarkets, and other non-traditional locations (Guillen and Tschoegl, 2000). Banks based in countries where banking is highly competitive and advanced have accumulated such intangibles, and can hence be expected to expand abroad to exploit them (Tschoegl, 2004). They are likely to take over banks in countries where banking is relatively less advanced but where the size of the market (the economic mass in a gravity model) is suf- ficiently large to provide benefits over the costs of entering these countries (Tschoegl, 1987).

Hypothesis 1a. Banks based in countries with highly developed banking are likely to engage in cross-border MEAs.

Hypothesis $1 \mathrm{~b}$. Banks based in countries with highly developed banking are likely to engage in cross-border MEAs in countries where the size of the market is sufficiently large to provide benefits over the costs of entering them.

The second reason why banks based in one country may want to engage in cross border M\&As derives from the first reason: because of the gains from transferring intangibles between bank agencies, the optimal scale of banking may be quite large relative to the size of the home country (Berger et al., 1993; Hughes and Mester, 2011). As a result, banking is highly concentrated in most national markets (Bergstresser, 2008). For firms that are already dominant in their home market, entering foreign markets may be the only way to grow (Vrontis and Sharp, 2003). This suggests that banks located in markets where banking activities are highly developed will take over or merge with banks located in countries which are less developed but have growth potential.

Hypothesis 1c. Banks based in highly concentrated markets will engage in cross-border ME'As.

The third reason why banks located in one country may want to take over banks located in another country has to do with a different type of intangibles. In the conduct of their domestic business, banks get to know their customers and establish trusting relationships with them. These relationships can then be leveraged when home-country commercial customers develop activities in foreign markets, or when home-country retail customers settle in foreign countries. This motive has been dubbed 'follow your customer'. It explains why banks establish operations to offer banking services in the foreign locations where their commercial customers have manufacturing or service subsidiaries (e.g. Focarelli and Pozzolo, 2001).

Hypothesis $1 d$. Banks are likely to engage in MEAs in countries where their commercial customers have located.

Follow the customer motives may also explain why banks may establish retail facilities in foreign locations where there is a concentration of nationals from their own country (Esperanca and Gulamhussen, 2001). Hence Portuguese banks established in the 1970s retail subsidiaries in Paris to serve the needs of Portuguese maids and butlers who had taken employment there and were eager to send money back to their families in Portugal (Pellerin, 2009; OECD, 1993). ${ }^{2}$ In 2001, Caixa Geral de Depositos acquired the Banque Franco-Portugaise with the explicit goal to increase its network of agencies to serve this population. ${ }^{3}$ Tschoegl (2005) notes that Japanese banks entered California early in the 20th century and again in the 1970s to serve the banking needs of Japanese emigrants. Similar motives are behind the foreign expansion of Singapore banks (Tschoegl, 2002). One would therefore expect the total level of banking M\&As from country $i$ to country $j$ to also be a function of the number of country i residents living in country $j$.

Hypothesis 1e. Banks are likely to engage in MEAs in countries where their retail customers have located.

\footnotetext{
2 According to OECD (1993), there were 50,000 Portuguese immigrants in France in 1962 and six years later they were 300,000. By 1975, 800,000 Portuguese had settled there. A Ukrainian bank has recently opened a subsidiary in Portugal to serve the growing Ukrainian immigrant community.

3 www.cgd-publishing.com/caixaempresas/marco2012/pdf.
} 
In spite of all the advantages to merging or acquiring foreign banks, researchers have noted that the level of international M\&A activity in banking is much lower than that observed in other service industries such as insurance (Focarelli and Pozzolo, 2008). Likewise, the level of international M\&As in banking is proportionally much lower than that of domestic M\&As (Caiazza et al., 2011), which suggests that there are high barriers to international expansion. Since there are no major differences in the type of banks targeted in domestic and international M\&As, target country characteristics would seem to be the main determinants of M\&A activity (Caiazza et al., 2012).

Banking is an information intensive industry. Successful lending, especially to smaller firms, requires a subtle understanding of their prospects and of their risk profile (Focarelli and Pozzolo, 2001). Obtaining this qualitative and often tacit information is difficult if lenders are distant from borrowers (Claessens and Van Horen, 2014b). Thus the farther away two countries are, the smaller should be the level of M\&A activity between them (Buch and DeLong, 2004). One can think of three dimensions of distance. One of them is geographic distance. Differences in the broader institutional environment (in language, religion, per capita income, levels of education, and political systems) may also make it difficult to do banking outside one's own country, and countries that do not share common institutional frameworks are less likely to be linked by M\&A activity as bank managers are less likely to expand in countries perceived to be dissimilar (Ellis, 2008). Time zone differences may also complicate the monitoring of foreign banking subsidiaries since they impede communication with $\mathrm{HQ}$.

$H 2 a, b, c$. The level of bank MEAs between two countries will be inversely proportional to the geographic (a), psychic (b) and time zone (c) distances between them.

A particular feature of banking is the high level of regulation. Host country regulatory agencies have therefore considerable opportunity to create additional barriers to the entry of foreign banks, and to make their life difficult after entry (Focarelli and Pozzolo, 2001).

$H 2 d$. Banks are less likely to engage in ME'As in countries which impose restrictions on foreign bank entry.

\section{Data, method and variables}

\subsection{Data}

We obtained data on the yearly number and value of banking M\&As from the SDC Platinum database published by Thomson Reuters. We focus on international M\&As that took place between 1980 and 2010 in which a commercial bank is either an acquirer or a target (there are no reliable data before 1980). We selected deals with a final stake of more than $50 \%$ (i.e. a majority stake). We excluded minority stakes, self-tenders, repurchases, and exchange offers, because they tend to be driven by different motives and their inclusion would introduce noise. We also excluded deals involving commercial banks located in offshores such as Aruba, Bermuda, the Cayman Islands, Guernsey, the Isle of Man and Mauritius, as the motivation to undertake activities in offshore centers is quite distinct from that in on-shore markets.

Our units of observation are the number and value of M\&As of banks in country $\mathrm{j}$ by banks in country $\mathrm{i}$ in year $\mathrm{t}$. We match the 89 acquiring countries to the 118 target countries to construct country pairs for each year between 1981 and 2010. Fig. 1 shows the number of M\&A deals in our sample and Fig. 2 their value between 1981 and 2010. Figs. 3 and 4 show the number and value of deals by country pairs. Fig. 3 shows that the South Africa-United Kingdom and United States-Canada pairs account for the largest number of deals (17 and 16, respectively), while Fig. 4 shows that the highest value of deals (more than 20 billion USD) was between the United Kingdom and the United States. Fig. 3 shows that there is no correlation between the number of deals between acquirertarget and target-acquirer country pairs, while Fig. 4 shows that this is also true for their value. Our sample also shows that U.S. banks made the largest number of acquisitions (248) with the highest value (74 billion USD) and that the US was also the largest target country, with 298 deals worth 131 billion USD. Missing data reduced our sample to 2157 deals corresponding to 1724 country pairs and a volume of deals in excess of 525 billion USD.

\subsection{Method}

Our dependent variables are whether country pairs have bank M\&As between them, and their value. These dependent variables are best explained in terms of a gravity model by which the occurrence and volume of M\&As between pairs of countries are directly proportional to their economic masses and the gravitational constant $G$, and inversely proportional to the square of distance separating them. The closed form of a standard gravity model is:

$$
\mathrm{F}_{\mathrm{ij}}=\mathrm{G} *\left(\mathrm{M}_{\mathrm{i}} * \mathrm{M}_{\mathrm{j}}\right) / \mathrm{D}_{\mathrm{ij}}^{2}
$$

where $F_{\mathrm{ij}}$ is the attraction force between two bodies, i and $\mathrm{j}, M$ is the mass of the two bodies, $\mathrm{i}$ and $\mathrm{j}, D$ is the distance between bodies, i and $\mathrm{j}$, and $G$ is a constant. The application of Eq. (1) to bilateral economic flows uses GDP as a measure for the size of the market. So Eq. (1) applied to economic flows becomes:

$$
\begin{aligned}
& \text { BILATERAL ECONOMIC FLOWS }_{\mathrm{i}, \mathrm{j}, \mathrm{t}} \\
& =\left(\mathrm{GDP}_{\mathrm{i}, \mathrm{t}}+\mathrm{GDP}_{\mathrm{j}, \mathrm{t}}\right) /\left(\text { DISTANCE }_{\mathrm{ij}}\right)^{2}
\end{aligned}
$$

Eq. (2) is a contained expression revealing that bilateral flows $\left(F_{\mathrm{ij}}\right)$ are an increasing function of the combined GDP (economic mass) of countries $i$ and $j$ but a rapidly decreasing function of the distance between country $\mathrm{i}$ and $\mathrm{j}$. In other words, bilateral economic flows will be significant if the product of the masses is high and the countries are close.

The usual way to run gravity models is to apply a logarithmic transformation to the right hand side of Eq. (2). By estimating the equation in logs, we obtain the following:

$$
\begin{aligned}
\text { M\&As }_{\mathrm{i}, \mathrm{j}, \mathrm{t}}= & \alpha+\beta_{\mathrm{k}} \log \text { MARKET POTENTIAL }_{\mathrm{i}, \mathrm{j}, \mathrm{t}}+\gamma_{\mathrm{k}} \text { DISTANCE }_{\mathrm{i}, \mathrm{j}, \mathrm{t}} \\
& +\sigma_{\mathrm{k}} \text { CONTROLS }_{\mathrm{i}, \mathrm{j}, \mathrm{t}}+\mathrm{a}_{\mathrm{t}}+\mathrm{u}_{\mathrm{i}, \mathrm{j}, \mathrm{t}}
\end{aligned}
$$

where M\&As are M\&A deals where country $i$ is the acquirer and country $\mathrm{j}$ is the target and $\mathrm{t}$ is the year (from 1980 to 2010). Our independent variables include estimates of the market sizes of the acquirer country $\mathrm{i}$ and target country $\mathrm{j}$, which in the latter case is measured by the expected growth of that country, and by the presence of corporate and non-corporate customers from the acquiring country i present in target country $\mathrm{j}$. The presence of corporate customers is proxied by the trade volume between the two countries while opportunities for retail banking business are proxied by the number of citizens of country i present in country j; DISTANCE is measured by the geographic and psychic distances between acquiring country $\mathrm{i}$ and target country $\mathrm{j}$, including the time zone differences between country $\mathrm{i}$ and country $\mathrm{j}$, and differences between country $\mathrm{i}$ and country $\mathrm{j}$ in economic freedom. The time effect is represented by $a_{t}$ and the error term is represented by $\mathrm{u}_{\mathrm{ij}, \mathrm{t}}$, which we can decompose in a fixed or in a random effect $\mu_{\mathrm{ij}}$ and a residual error term $\varepsilon_{\mathrm{ij}, \mathrm{t}}$. In Table 1 , we describe our variables and their sources. 
Table 1

Variables and sources.

\begin{tabular}{|c|c|c|c|c|c|c|}
\hline Variables & Description & Mean Std. dev. & Min. & Max. & Units & Source \\
\hline \multicolumn{7}{|l|}{ Dependent variables } \\
\hline NUMBER & number of cross-border M\&As & $\begin{array}{l}0.137 \\
1.083\end{array}$ & 0 & 47 & number & Thomson Reuters (SDC Platinum) \\
\hline VALUE & volume of cross-border M\&As & $\begin{array}{l}1406.568 \\
3774.267\end{array}$ & 0 & 9459.380 & million USD & Thomson Reuters (SDC Platinum) \\
\hline \multicolumn{7}{|l|}{$\begin{array}{l}\text { Independent variables } \\
\text { Market sizes }\end{array}$} \\
\hline LOG SIZE (acquirer) & $\begin{array}{l}\text { log of the GDP of the acquirer } \\
\text { country as a measure of its } \\
\text { economic size. }\end{array}$ & $\begin{array}{l}8.676 \\
1.456\end{array}$ & 5.319 & 11.678 & $\log ($ million USD) & S\&P, Global Stock Markets Factbook \\
\hline $\begin{array}{l}\text { LOG FINANCIAL DEPTH } \\
\text { (acquirer) }\end{array}$ & $\begin{array}{l}\text { log of the sum of market } \\
\text { capitalization and private credit of } \\
\text { the target country, both scaled to } \\
\text { GDP, as a measure of the overall } \\
\text { size of the financial sector; before } \\
\text { applying the log we add one to } \\
\text { the previous sum to obtain } \\
\text { positive values }\end{array}$ & 0.810 & 2.230 & 6.286 & $\log ($ million USD) & $\begin{array}{l}\text { IMF, International Financial } \\
\text { Statistics and data files, and } \\
\text { World Bank and OECD estimates }\end{array}$ \\
\hline $\begin{array}{l}\text { CONCENTRATION - HHI } \\
\text { (acquirer) }\end{array}$ & $\begin{array}{l}\text { Herfindhal-Hirschman index (HHI) } \\
\text { of concentration computed as the } \\
\text { sum of the squared market shares } \\
\text { of the acquiring country's banks; } \\
\text { a value of one denotes monopoly. }\end{array}$ & $\begin{array}{l}0.518 \\
0.338\end{array}$ & 0 & 1 & ratio & $\begin{array}{l}\text { Beck et al. (2001) - The financial } \\
\text { structure database }\end{array}$ \\
\hline $\begin{array}{l}\text { LOG UNEXPLORED MARKET } \\
\text { (target) }\end{array}$ & $\begin{array}{l}\text { log of the difference between the } \\
\text { financial depth of the target } \\
\text { country and that of the U.S. }\end{array}$ & $\begin{array}{l}29.193 \\
3.736\end{array}$ & 0 & 30.318 & $\log ($ million USD) & $\begin{array}{l}\text { IMF, International Financial } \\
\text { Statistics and data files, and } \\
\text { World Bank and OECD estimates }\end{array}$ \\
\hline LOG GDP GROWTH (target) & $\begin{array}{l}\text { log of the GDP annual growth in the } \\
\text { target country computed as the } \\
\text { first differences of a normalized } \\
\text { series }\end{array}$ & $\begin{array}{l}3.787 \\
1.075\end{array}$ & -0.800 & 6.270 & number & $\begin{array}{l}\text { IMF, International Financial } \\
\text { Statistics and data files, and } \\
\text { World Bank and OECD estimates }\end{array}$ \\
\hline LOG GDP RESIDUAL (target) & $\begin{array}{l}\text { log of the residual error, computed } \\
\text { as the difference between the } \\
\text { actual GDP in the target country } \\
\text { and its estimated value by a } \\
\text { linear regression of the } \\
\text { normalized GDP series from } 1976 \\
\text { to } 2009\end{array}$ & $\begin{array}{l}3.161 \\
1.044\end{array}$ & -2.117 & 5.896 & number & $\begin{array}{l}\text { IMF, International Financial } \\
\text { Statistics and data files, and } \\
\text { World Bank and OECD estimates }\end{array}$ \\
\hline LOG BILATERAL TRADE & $\begin{array}{l}\text { log of bilateral trade between } \\
\text { acquirer and target countries, } \\
\text { adding one unit to the effective } \\
\text { value before computing the log }\end{array}$ & $\begin{array}{l}1.968 \\
1.209\end{array}$ & 0.000 & 5.771 & number & $\begin{array}{l}\text { IMF, International Financial } \\
\text { Statistics Database, Direction of } \\
\text { Trade Statistics } \\
\text { (www2.imfstatistics.org/DOT/) }\end{array}$ \\
\hline LOG MIGRANTS & $\begin{array}{l}\text { log of the number of people born in } \\
\text { the acquirer country i that live in } \\
\text { the target country; we add one } \\
\text { unit to the effective value before } \\
\text { computing the log }\end{array}$ & $\begin{array}{l}1.874 \\
1.794\end{array}$ & 0.000 & 7.066 & $\log$ (thousands) & $\begin{array}{l}\text { Ratha and Shaw (2007), Migrants } \\
\text { and Remittances Factbook 2011, } \\
\text { the Word Bank }\end{array}$ \\
\hline \multicolumn{7}{|l|}{ Distances } \\
\hline$\overline{\text { LOG GEOGRAPHIC DISTANCE }}$ & $\begin{array}{l}\text { log of the geographic distance } \\
\text { between acquirer and target } \\
\text { countries; we add one unit to the } \\
\text { effective value before computing } \\
\text { the log }\end{array}$ & $\begin{array}{l}3.808 \\
0.362\end{array}$ & 2.260 & 4.296 & number & $\begin{array}{l}\text { CEPII (www.cepii.fr/anglaisgraph/ } \\
\text { bdd/distances.htm) }\end{array}$ \\
\hline PSYCHIC DISTANCE & $\begin{array}{l}\text { perceived degree of similarities in } \\
\text { the characteristics of pairs of } \\
\text { countries }\end{array}$ & $\begin{array}{c}-0.202 \\
1.195\end{array}$ & -4.346 & 0.526 & number & $\begin{array}{l}\text { Douglas Dow } \\
\quad(\text { sites.google.com/site/ddowresearch/) }\end{array}$ \\
\hline TIME ZONE & $\begin{array}{l}\text { time difference between acquirer } \\
\text { and target countries, in absolute } \\
\text { value }\end{array}$ & $\begin{array}{l}0.473 \\
0.832\end{array}$ & 0 & 18 & integer & $\begin{array}{l}\text { (http://time-zone.tripod.com/ } \\
\text { timezones2.htm) }\end{array}$ \\
\hline REGULATORY RESTRICTIONS & $\begin{array}{l}\text { limitations on foreign bank } \\
\text { entry/ownership; measures the } \\
\text { extent to which foreign banks are } \\
\text { allowed to enter the target } \\
\text { country }\end{array}$ & $\begin{array}{l}3.798 \\
6.339\end{array}$ & 1 & 4 & number & $\begin{array}{l}\text { World Banks surveys on bank } \\
\text { regulation by Barth, R. Caprio, G. } \\
\text { \& Levine, R. } \\
\text { (www.worldbank.org) }\end{array}$ \\
\hline
\end{tabular}


Table 1 (continued)

\begin{tabular}{|c|c|c|c|c|c|c|}
\hline Variables & Description & Mean Std. dev. & Min. & Max. & Units & Source \\
\hline \multicolumn{7}{|l|}{ Controls } \\
\hline FINANCIAL OPENNESS & $\begin{array}{l}\text { country de jure degree of capital } \\
\text { account openness, based on } \\
\text { dummy variables that codify the } \\
\text { tabulation of restrictions on } \\
\text { cross-border financial transactions }\end{array}$ & $\begin{array}{l}0.210 \\
1.571 \\
\end{array}$ & -1.889 & 2.390 & number & $\begin{array}{l}\text { Chinn-Ito index (Chinn and Ito, } \\
\text { 2006) }\end{array}$ \\
\hline $\begin{array}{l}\text { DIFFERENCES IN ECONOMIC } \\
\text { FREEDOM }\end{array}$ & $\begin{array}{l}\text { difference between acquirer and } \\
\text { target countries in the average } \\
\text { score based on } 10 \text { measures of } \\
\text { economic openness, regulatory } \\
\text { efficiency and rule of law }\end{array}$ & $\begin{array}{r}-0.307 \\
0.009\end{array}$ & -0.369 & -0.301 & number & $\begin{array}{l}\text { The Heritage Foundation } \\
\text { (http://www.heritage.org/Index/) }\end{array}$ \\
\hline COMPETITIVENESS & $\begin{array}{l}\text { overall competitiveness, as a proxy } \\
\text { for the attractiveness of the target } \\
\text { country, measured by the IMD } \\
\text { index }\end{array}$ & $\begin{array}{l}60.883 \\
21.415\end{array}$ & 0 & 100 & number & $\begin{array}{l}\text { IMD Index - International Institute } \\
\text { for Management Development } \\
\text { (www.imd.org/research/centers/ } \\
\text { wcc/index.cfm) }\end{array}$ \\
\hline
\end{tabular}

\subsection{Variables}

\subsubsection{Dependent variables}

Our dependent variables are whether or not country pairs have completed M\&A deals, and their value.

\subsubsection{Independent variables}

3.3.2.1. Market size. According to the gravity model, the occurrence of cross-border M\&As and their value should depend on the size of the acquiring country. Along with Claessens and Van Horen (2014b), we measure that size, LOG SIZE (acquirer), by the log of its GDP. Hypothesis 1a states that the greater the level of intangibles held by the banks of a focal country, the more likely they will engage in cross-border M\&As. Along with Focarelli and Pozzolo (2008), we assume that these intangibles are proportional to the financial depth of the acquiring country, LOG FINANCIAL DEPTH (acquirer), which is the log of a country's sum of the stock market capitalization and credit to the private sector, both scaled by its GDP. Stock market capitalization is measured by the number of outstanding shares of listed companies on the stock market multiplied by their share price, and credit to the private sector (henceforth private credit) is the financing to the economy by both bank and non-bank intermediaries.

We used three measures to test Hypothesis $1 \mathrm{~b}$ which states that the number and volume of M\&As received by a target country will be a function of the size of its market. LOG UNEXPLORED MARKET (target) measures market opportunities in the target country. We computed this variable as the log of the difference between the financial depth of the target country (as defined earlier) and that of the world's most developed banking market, the U.S. We collected data for this variable from the IMF, the OECD and the World Bank. We would also expect banks to be attracted to rapidly growing countries. Following Focarelli and Pozzolo (2006) we entered the annual GDP growth in the target country, LOG GDP GROWTH. We computed the annual growth for target country $\mathrm{j}$ as:

$$
\text { GDP GROWTH }_{\mathrm{j}, \mathrm{t}}=\left(\mathrm{GDP}_{\mathrm{j}, \mathrm{t}}-\mathrm{GDP}_{\mathrm{j}, \mathrm{t}-1}\right) / \mathrm{GDP}_{\mathrm{j}, \mathrm{t}-1}
$$

We normalized annual growth by dividing GDP by the GDP of the first year of the period that then takes the value 100. We chose 1976 as the base year (GDP =100). GDP growth is then computed as the first differences of the normalized GDP series (Kogut, 1991; Anderson, 1979). Our measure of annual growth of the target country becomes:

LOGGDP GROWTH $_{\mathrm{j}, \mathrm{t}}=\operatorname{LOG}\left(\mathrm{GDP}_{\mathrm{j}, \mathrm{t}}-\mathrm{GDP}_{\mathrm{j}, \mathrm{t}-1}\right)$
Lastly, it is possible that banks are deterred by unstable conditions and seek markets with stable growth (Clare et al., 2012). We therefore enter a measure of the variation of the target market GDP growth, LOG GDP RESIDUAL (target). We calculated the residual error (GDP RESIDUAL) from a linear regression of the time trend of GDP over our period of analysis, where we estimate the slope (a) and the intercept (b). The residual error is the difference between the real GDP for a particular country $\mathrm{j}$ and the fitted GDP line derived from the linear regression, for a particular year $t$. We used the normalized GDP series to compute the residual error and log the result (Kogut, 1991; Anderson, 1979). The closed form is:

$\operatorname{LOGR}_{\mathrm{j}, \mathrm{t}}=\operatorname{LOG}\left[\operatorname{GDP}_{\mathrm{j}, \mathrm{t}}-\left(\mathrm{a}_{\mathrm{j}}+\mathrm{b}_{\mathrm{j}} * \mathrm{t}\right)\right]$

Hypothesis 1c states that banks operating in concentrated markets are more likely to make foreign M\&As because they are faced with limited domestic opportunities. We measure banking concentration in the acquiring country by its Herfindhal-Hirschman concentration indices, CONCENTRATION HHI, computed by Beck et al. (2001). This variable is the sum of the squared market shares of the acquiring country's banks. It ranges from its lowest value (the reciprocal of the number of banks in an economy when all are of the same size) to one in the case of monopoly.

Following Focarelli and Pozzolo (2001), the market potential to banks from the acquiring country from serving their home-country corporate customers in the target country (Hypothesis 1d) is proxied by the level of bilateral trade between acquirer and target countries, LOG BILATERAL TRADE. The higher the level of trade between two countries, the greater the probability that commercial customers of the home-country bank will be present in the target country (Buch and DeLong, 2004). We measure this variable as the $\log$ of the total value of trade (the sum of imports and exports) between the acquiring and the target country. Data were collected from the IMF (www2.imfstatistics.org/DOT/).

We use the variable LOG MIGRANTS to test Hypothesis 1e. This variable measures the market potential to acquiring country banks of serving non-corporate customers from their own country that reside in the target country (Esperanca and Gulamhussen, 2001). It is measured by the log of the number of persons born in country $i$ who are living in country $\mathrm{j}$ without being permanent residents of that country. Data was obtained from Ratha and Shaw (2007) and the Word Bank (www.data.worldbank.org).

3.3.2.2. Distances. We use three measures of distance to test Hypotheses 2a, 2b and 2c. LOG GEOGRAPHIC DISTANCE measures the cost of managing activities in distant geographic locations (Buch and DeLong, 2004; Martin and Rey, 2004; Giovanni, 2005). 
Table 2

Correlation matrix.

\begin{tabular}{|c|c|c|c|c|c|c|c|c|c|c|c|c|c|c|c|c|}
\hline & 1 & 2 & 3 & 4 & 5 & 6 & 7 & 8 & 9 & 10 & 11 & 12 & 13 & 14 & 15 & 16 \\
\hline 1 NUMBER OF DEALS & 1 & & & & & & & & & & & & & & & \\
\hline 2 VALUE OF DEALS & 0.827 & 1 & & & & & & & & & & & & & & \\
\hline 3 LOG SIZE (acquirer) & 0.066 & 0.052 & 1 & & & & & & & & & & & & & \\
\hline $\begin{array}{l}4 \text { LOG FINANCIAL DEPTH } \\
\text { (acquirer) }\end{array}$ & 0.096 & 0.073 & 0.637 & 1 & & & & & & & & & & & & \\
\hline $\begin{array}{l}5 \text { CONCENTRATION } \\
\text { (acquirer) }\end{array}$ & 0.011 & 0.008 & 0.228 & 0.094 & 1 & & & & & & & & & & & \\
\hline $\begin{array}{l}6 \text { LOG UNEXPLORED } \\
\text { MARKET (target) }\end{array}$ & -0.481 & -0.452 & -0.037 & -0.066 & 0.094 & 1 & & & & & & & & & & \\
\hline $\begin{array}{l}7 \text { LOG GDP GROWTH } \\
\text { (target) }\end{array}$ & 0.000 & -0.003 & 0.127 & 0.111 & 0.105 & 0.067 & 1 & & & & & & & & & \\
\hline $\begin{array}{l}8 \text { LOG GDP RESIDUAL } \\
\text { (target) }\end{array}$ & -0.039 & -0.033 & 0.106 & 0.103 & 0.096 & 0.080 & 0.601 & 1 & & & & & & & & \\
\hline 9 LOG BILATERAL TRADE & 0.296 & 0.219 & 0.231 & 0.297 & 0.081 & -0.216 & 0.153 & 0.136 & 1 & & & & & & & \\
\hline 10 LOG MIGRANTS & 0.272 & 0.195 & 0.028 & 0.042 & 0.010 & -0.184 & -0.009 & -0.130 & 0.599 & 1 & & & & & & \\
\hline $\begin{array}{l}11 \text { LOG GEOGRAPHIC } \\
\text { DISTANCE }\end{array}$ & -0.147 & -0.096 & 0.020 & -0.003 & -0.057 & -0.014 & 0.010 & 0.031 & -0.347 & -0.246 & 1 & & & & & \\
\hline 12 PSYCHIC DISTANCE & $-\mathbf{0 . 1 7 0}$ & $-\mathbf{0 . 1 0 7}$ & -0.074 & -0.002 & 0.021 & 0.075 & 0.024 & 0.029 & -0.102 & -0.212 & 0.154 & 1 & & & & \\
\hline 13 TIME ZONE & -0.065 & -0.039 & 0.011 & -0.069 & 0.019 & -0.097 & -0.069 & 0.002 & 0.025 & 0.030 & -0.022 & -0.016 & 1 & & & \\
\hline $\begin{array}{l}14 \text { REGULATORY } \\
\text { RESTRICTIONS (target) }\end{array}$ & 0.036 & 0.021 & -0.016 & -0.018 & -0.020 & -0.040 & -0.094 & -0.043 & 0.073 & 0.118 & -0.057 & 0.041 & -0.034 & 1 & & \\
\hline $\begin{array}{l}15 \text { FINANCIAL OPENNESS } \\
\text { (target) }\end{array}$ & 0.096 & 0.074 & 0.085 & 0.047 & 0.109 & -0.043 & 0.166 & 0.093 & 0.128 & 0.291 & 0.281 & -0.061 & -0.013 & -0.169 & 1 & \\
\hline $\begin{array}{l}16 \text { DIFFERENCES IN } \\
\text { ECONOMIC FREEDOM }\end{array}$ & -0.038 & -0.036 & -0.015 & 0.119 & -0.030 & -0.008 & 0.020 & 0.093 & -0.011 & -0.130 & 0.051 & 0.102 & 0.022 & 0.022 & -0.074 & 1 \\
\hline $\begin{array}{l}17 \text { COMPETITIVENENESS } \\
\text { (target) }\end{array}$ & 0.097 & 0.081 & 0.019 & 0.049 & 0.016 & -0.123 & 0.076 & -0.064 & 0.269 & 0.395 & 0.013 & -0.046 & -0.131 & 0.126 & 0.476 & -0.007 \\
\hline
\end{tabular}

Numbers in bold denote significance at the $1 \%$ level.

We measure it by the log of the geographic distance between the capitals of the acquiring and target countries. We collected data for this variable from CEPII (www.cepii.fr/anglaisgraph/bdd/distances. $\mathrm{htm}$ ). PSYCHIC DISTANCE is a comprehensive measure of the distance between acquiring country $\mathrm{i}$ and target country $\mathrm{j}$ in language, religion, industrial development, levels of education, and political systems. We downloaded the data for this variable from Douglas Dow's website (https://sites.google.com/site/ddowresearch/), which provides a complete description. TIME ZONE (difference between acquirer and target) is the absolute time difference between acquirer and target countries: the greater the time difference between acquirer and target, the more difficult it will be for HQ to communicate with its foreign acquisitions, and hence the less desirable the country as a target for acquisitions.

Lastly we entered REGULATORY RESTRICTIONS (target). This variable measures whether foreign banks are permitted to enter and own banks in the target country (Barth et al., 2013). We collected data for this variable from surveys of bank regulators and supervisors conducted by the World Bank in 180 countries. For instance, China and Indonesia impose foreign equity limits while OECD countries have relatively fewer restrictions on foreign equity ownership. We used the results of the 2001, 2003, 2007 and 2012 surveys.

\subsection{Estimation}

Our data are censored at zero as there are several country pairs for which the number and value of M\&As are zero. A possible approach to estimate the gravity model might be two-step estimation such as the Heckman selection model (Heckman, 1979). Twostep estimation procedures distinguish between the probability of an M\&A (first step) and the value of M\&A deals (second step), similar to the distinction between extensive and intensive margins in trade theory models (Melitz, 2003; Helpman et al., 2007; Brakman et al., 2014). However two-step estimation requires an adequate exclusion restriction for identification of the second step, which is sometimes difficult. To avoid having to find an appropri- ate exclusion restriction - a variable influencing the probability of doing an M\&A (first step) but not their value (second step) - we follow Lambert's (1992) zero-inflated approach as in Brakman et al. (2014). This approach contemplates a combination of probability distributions representing two processes: one zero-process in which only zeros are detected (i.e. Bernoulli), and a truncated process (e.g. Poisson or negative binomial) in which zero and nonzero values are observed (Lambert, 1992). This succinct approach is similar to a Heckman estimation procedure but is less restrictive and builds on two groups of observations: (i) observations that have a zero outcome with a probability 1, and (ii) observations that might be zero or non-zero. As in Brakman et al. (2014) we estimate the probability of doing an M\&A with a logit and model the value of the $M \& A$ deals with a zero-inflated negative binomial (ZINB) specification. The use of ZINB is recommended by Anderson and Wincoop (2003), Cameron and Trivedi (2009) and Anderson (2011), and ZINB is used by Santos-Silva and Tenreyro (2006) and Brakman et al. (2014) because it accommodates excess zeros and over-dispersion of the dependent variable, a phenomenon often observed in large counts. ${ }^{4}$ We run the Vuong test of the zeroinflated versus the standard model as suggested by Cameron and Trivedi (2009). The significant z-test confirms that a zero-inflated model is a better fit. Our specifications include country fixed effects to account for unobserved country characteristics and year fixed effects to account for unobserved time-variant effects.

The descriptive statistics of our data are in Table 1 , and the pairwise correlations between our variables in Table 2. The correlations are generally low, suggesting no linear dependence between our independent variables.

\footnotetext{
4 The negative binomial model is a generalization of the Poisson model. A key restriction of the Poisson distribution is that the variance equals the mean. Since unobserved heterogeneity can cause overdispersion of the data, the negative binomial model enters an unobserved effect in the conditional mean of the dependent variable to allow for overdispersion (Wooldridge, 2010; Brakman et al., 2014).
} 
Table 3

Determinants of cross-border acquisitions in commercial banking.

\begin{tabular}{|c|c|c|c|c|c|c|c|c|c|}
\hline \multirow[t]{2}{*}{ Dependent: } & \multirow{2}{*}{$\begin{array}{l}\text { Probability of M\&As } \\
\text { Logit coeff. } \\
\text { (1) }\end{array}$} & \multicolumn{2}{|l|}{ M\&A Value } & \multirow{2}{*}{$\begin{array}{l}\text { Probability of M\&As } \\
\text { Logit coeff. } \\
\text { (4) }\end{array}$} & \multicolumn{2}{|l|}{ M\&A Value } & \multirow{2}{*}{$\begin{array}{l}\text { Probability of M\&As } \\
\text { Logit coeff. } \\
\text { (7) }\end{array}$} & \multicolumn{2}{|l|}{ M\&A Value } \\
\hline & & $\begin{array}{l}\text { ZINB coeff. } \\
\text { (2) }\end{array}$ & $\begin{array}{l}\text { IRR } \\
(3)\end{array}$ & & $\begin{array}{l}\text { ZINB coeff. } \\
\text { (5) }\end{array}$ & $\begin{array}{l}\text { IRR } \\
(6)\end{array}$ & & $\begin{array}{l}\text { ZINB coeff. } \\
\text { (8) }\end{array}$ & $\begin{array}{l}\text { IRR } \\
(9)\end{array}$ \\
\hline \multicolumn{10}{|l|}{ Market sizes - acquirer } \\
\hline LOG SIZE (acquirer) & $\begin{array}{l}0.070 \\
(0.103)\end{array}$ & $\begin{array}{l}0.151^{* * *} \\
(0.036)\end{array}$ & 1.163 & $\begin{array}{l}0.023 \\
(0.095)\end{array}$ & $\begin{array}{l}0.097^{* *} \\
(0.038)\end{array}$ & 1.102 & $\begin{array}{l}0.023 \\
(0.095)\end{array}$ & $\begin{array}{l}0.106^{* * * *} \\
(0.038)\end{array}$ & 1.112 \\
\hline LOG FINANCIAL DEPTH (acquirer) & $\begin{array}{l}0.379 * * \\
(0.193)\end{array}$ & $\begin{array}{l}0.441^{* * *} \\
(0.077)\end{array}$ & 1.555 & $\begin{array}{l}0.377^{* *} \\
(0.187)\end{array}$ & $\begin{array}{l}0.290^{* * *} \\
(0.075)\end{array}$ & 1.336 & $\begin{array}{l}0.376^{* *} \\
(0.187)\end{array}$ & $\begin{array}{l}0.337 * * * \\
(0.079)\end{array}$ & 1.401 \\
\hline CONCENTRATION - HHI (acquirer) & $\begin{array}{l}-0.257 \\
(0.325)\end{array}$ & $\begin{array}{l}0.022 \\
(0.137)\end{array}$ & & $\begin{array}{l}-0.193 \\
(0.295)\end{array}$ & $\begin{array}{l}-0.304^{* *} \\
(0.135)\end{array}$ & 0.738 & $\begin{array}{c}-0.193 \\
(0.295)\end{array}$ & $\begin{array}{l}-0.178 \\
(0.144)\end{array}$ & \\
\hline \multicolumn{10}{|l|}{ Market sizes - target } \\
\hline LOG UNEXPLORED MARKET (target) & $\begin{array}{l}-0.042^{* *} \\
(0.021)\end{array}$ & $\begin{array}{l}-0.105^{* * *} \\
(0.015)\end{array}$ & 0.900 & $\begin{array}{l}-0.040^{*} \\
(0.022)\end{array}$ & $\begin{array}{c}-0.094^{* * * *} \\
(0.006)\end{array}$ & 1.099 & $\begin{array}{l}-0.040^{*} \\
(0.022)\end{array}$ & $\begin{array}{l}-0.087^{* * * *} \\
(0.006)\end{array}$ & 0.917 \\
\hline LOG GDP GROWTH (target) & $\begin{array}{l}-0.034 \\
(0.021)\end{array}$ & $\begin{array}{l}-0.162^{* *} \\
(0.082)\end{array}$ & 0.850 & $\begin{array}{l}-0.032 \\
(0.026)\end{array}$ & $\begin{array}{l}-0.127 \\
(0.077)\end{array}$ & & $\begin{array}{l}-0.032 \\
(0.026)\end{array}$ & $\begin{array}{l}-0.148^{*} \\
(0.088)\end{array}$ & 0.863 \\
\hline LOG GDP RESIDUAL (target) & $\begin{array}{l}0.029 * \\
(0.015)\end{array}$ & $\begin{array}{l}-0.058 \\
(0.072)\end{array}$ & & $\begin{array}{l}0.025 \\
(0.017)\end{array}$ & $\begin{array}{l}-0.074 \\
(0.064)\end{array}$ & & $\begin{array}{l}0.025 \\
(0.017)\end{array}$ & $\begin{array}{l}-0.082 \\
(0.074)\end{array}$ & \\
\hline \multicolumn{10}{|l|}{ Market sizes - acquirer-target } \\
\hline LOG BILATERAL TRADE & $\begin{array}{l}0.937 \text { **** } \\
(0.178)\end{array}$ & $\begin{array}{l}1.612^{* * * *} \\
(0.057)\end{array}$ & 5.011 & $\begin{array}{l}1.053^{\text {***** }} \\
(0.167)\end{array}$ & $\begin{array}{l}1.135^{* * * *} \\
(0.059)\end{array}$ & 3.111 & $\begin{array}{l}1.053^{* * *} \\
(0.167)\end{array}$ & $\begin{array}{l}1.272^{* * * *} \\
(0.064)\end{array}$ & 3.570 \\
\hline LOG MIGRANTS & $\begin{array}{l}0.325^{* * *} \\
(0.086)\end{array}$ & $\begin{array}{l}0.696 * * * \\
(0.031)\end{array}$ & 2.006 & $\begin{array}{l}0.321^{* * *} \\
(0.091)\end{array}$ & $\begin{array}{l}0.507 * * * \\
(0.031)\end{array}$ & 1.660 & $\begin{array}{l}0.321^{\text {**** }} \\
(0.091)\end{array}$ & $\begin{array}{l}0.549 * * * \\
(0.030)\end{array}$ & 1.732 \\
\hline \multicolumn{10}{|l|}{ Distances } \\
\hline LOG GEOGRAPHIC DISTANCE & $\begin{array}{l}-0.584 \\
(0.526)\end{array}$ & $\begin{array}{l}-0.605^{*} \\
(0.344)\end{array}$ & 0.546 & $\begin{array}{l}-0.362 \\
(0.394)\end{array}$ & $\begin{array}{l}-0.487^{* * * *} \\
(0.128)\end{array}$ & 0.615 & $\begin{array}{l}-0.362 \\
(0.393)\end{array}$ & $\begin{array}{l}-0.535^{* * * *} \\
(0.149)\end{array}$ & 0.586 \\
\hline $\begin{array}{l}\text { LOG GEOGRAPHIC DISTANCE * } \\
\text { TIME TREND }\end{array}$ & $\begin{array}{l}0.002 \\
(0.012)\end{array}$ & $\begin{array}{l}-0.024^{*} \\
(0.013)\end{array}$ & 0.976 & & & & & & \\
\hline PSYCHIC DISTANCE & $\begin{array}{l}-0.457^{* * *} \\
(0.113)\end{array}$ & $\begin{array}{l}-0.506^{* * *} \\
(0.028)\end{array}$ & 0.603 & $\begin{array}{l}-0.485^{* * *} \\
(0.112)\end{array}$ & $\begin{array}{l}-0.297^{* * *} \\
(0.070)\end{array}$ & 0.743 & $\begin{array}{l}-0.491^{* * *} \\
(0.106)\end{array}$ & $\begin{array}{l}-0.442^{* * *} \\
(0.029)\end{array}$ & 0.643 \\
\hline PSYCHIC DISTANCE $*$ TIME TREND & & & & $\begin{array}{l}0.000 \\
(0.002)\end{array}$ & $\begin{array}{l}-0.005^{*} \\
(0.003)\end{array}$ & 0.995 & & & \\
\hline TIME ZONE & $\begin{array}{l}-0.089^{* *} \\
(0.044)\end{array}$ & $\begin{array}{l}-0.446^{* * *} \\
(0.015)\end{array}$ & 0.640 & $\begin{array}{l}-0.074^{*} \\
(0.043)\end{array}$ & $\begin{array}{l}-0.409^{* * *} \\
(0.015)\end{array}$ & 0.664 & $\begin{array}{l}-0.074^{*} \\
(0.043)\end{array}$ & $\begin{array}{l}-0.400^{* * *} \\
(0.014)\end{array}$ & 0.670 \\
\hline REGULATORY RESTRICTIONS & & & & & & & $\begin{array}{l}0.108 \\
(0.096)\end{array}$ & $\begin{array}{l}-0.267^{*} \\
(0.132)\end{array}$ & 0.766 \\
\hline Intercept & $\begin{array}{l}-5.343^{* *} \\
(2.101)\end{array}$ & $\begin{array}{l}6.423^{* * *} \\
(1.270)\end{array}$ & & $\begin{array}{l}-6.633^{* * *} \\
(1.962)\end{array}$ & $\begin{array}{l}6.732 * * * \\
(0.854)\end{array}$ & & $\begin{array}{l}-6.634^{* * *} \\
(1.362)\end{array}$ & $\begin{array}{l}0.346^{* * *} \\
(0.051)\end{array}$ & \\
\hline Year effects & Yes & Yes & & Yes & Yes & & Yes & Yes & \\
\hline Country effects & Yes & Yes & & Yes & Yes & & Yes & Yes & \\
\hline Number of observations & 27,147 & 31,535 & & 24,059 & 31,535 & & 24,059 & 27,516 & \\
\hline
\end{tabular}

Standard errors are in parentheses. Significance at the $1 \%, 5 \%$, and $10 \%$ levels is denoted by $* * *$, $* *$ and $*$, respectively.

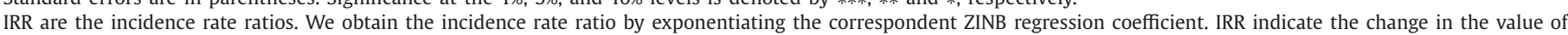
M\&As if a variable changes by one unit.

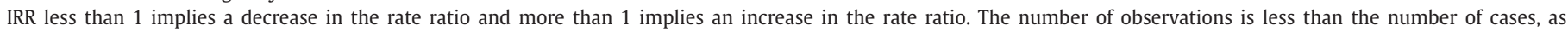
incomplete cases for some variables are excluded and some cases are dropped to avoid collinearity.

\section{Results}

We present the estimation results of our baseline specification in Table 3. Panels 1, 4, and 7 provide the estimates for the probability of a country pair having M\&As, whilst Panels 2-3, 5-6, and 8-9 display the estimates and the incidence rate ratios (IRR) for the value of M\&As. Panels $1-3$ and 4-6 include the interaction of our distance variables (GEOGRAPHIC DISTANCE and PSYCHIC DISTANCE) with a time trend. In Panels 7-9 we enter the variable REGULATORY RESTRICTIONS as an additional variable to measure regulatory limits on the entry of foreign banks and on their ownership in the target country.

We find that the size of the acquirer's home country is not a prerequisite for M\&As (LOG SIZE is not significant in Panels 1, 4 and 7 of Table 3 ) but the larger the size of the acquirer's home country, the larger the value of M\&As (LOG SIZE is positive and significant at the $1 \%$ confidence level in Panels 2, 5 and 8). The IRRs show that an increase in one unit of LOG SIZE corresponds to an increase above 1.1 of the volume of M\&As, holding all other variables constant. In H1a and b we hypothesized that banks in countries with highly developed bank markets have accumulated technical, marketing, and managerial skills, which they can exploit in target countries; hence these countries would be more likely to engage in cross-border M\&As. As predicted, the coefficient of LOG FINANCIAL DEPTH, which measures the maturity of financial institutions in the acquiring country, is positive and significant at the $5 \%$ confidence level for the probability of having M\&As and at the $1 \%$ confidence level for their value. Both coefficients show similar economic significance (the coefficient estimates are only slightly higher for the probability of M\&As, 0.376-0.379, than for their value, 0.290-0.441). Focarelli and Pozzolo (2008), who investigated the factors influencing the number of cross-border M\&As in banking and insurance, also found this variable to be significant. One often argued motivation for foreign expansion is saturation in the home market, and hence in H1c we argued that banks in countries with high banking concentration would be more likely to engage in cross-border M\&As. Our results are not supportive, since the coefficient of CONCENTRATION-HHI, the concentration ratio in the home banking market, is generally not significant (except in panel 5 where it takes the wrong sign). We had also hypothesized in H1d that banks engage in cross-border M\&As to leverage the relationships they have established with their domestic corporate customers. This implies that the level of banking M\&As between two countries should be related to the volume of trade between them. As predicted, LOG BILATERAL TRADE, the log of the value of trade between a country pair, is positive and sig- 


\begin{tabular}{|c|c|c|c|c|c|c|c|c|c|}
\hline & \multicolumn{3}{|c|}{ Financial Openness (Chinn-Ito index) } & \multicolumn{3}{|c|}{ Differences in Economic Freedom } & \multicolumn{3}{|c|}{ Competitiveness (IMD index) } \\
\hline & \multirow{2}{*}{$\begin{array}{l}\text { Probability of M\&As } \\
\text { Logit coeff. } \\
\text { (1) }\end{array}$} & \multicolumn{2}{|c|}{ Value of M\&As } & \multirow{2}{*}{$\begin{array}{l}\text { Probability of M\&As } \\
\text { Logit coeff. } \\
\text { (4) }\end{array}$} & \multicolumn{2}{|c|}{ Value of M\&As } & \multirow{2}{*}{$\begin{array}{l}\text { Probability of M\&As } \\
\text { Logit coeff. } \\
\text { (7) }\end{array}$} & \multicolumn{2}{|c|}{ Value of M\&As } \\
\hline & & $\begin{array}{l}\text { ZINB coeff. } \\
\text { (2) }\end{array}$ & $\begin{array}{l}\text { IRR } \\
(3)\end{array}$ & & $\begin{array}{l}\text { ZINB coeff. } \\
\text { (5) }\end{array}$ & $\begin{array}{l}\text { IRR } \\
(6)\end{array}$ & & $\begin{array}{l}\text { ZINB coeff. } \\
\text { (8) }\end{array}$ & $\begin{array}{l}\text { IRR } \\
(9)\end{array}$ \\
\hline \multicolumn{10}{|l|}{ Market sizes - acquirer } \\
\hline LOG SIZE (acquirer) & $\begin{array}{l}0.076 \\
(0.106)\end{array}$ & $\begin{array}{l}0.354^{* * *} \\
(0.041)\end{array}$ & 1.425 & $\begin{array}{l}0.087 \\
(0.132)\end{array}$ & $\begin{array}{l}0.077 \\
(0.066)\end{array}$ & & $\begin{array}{l}0.115 \\
(0.114)\end{array}$ & $\begin{array}{l}0.441^{* * *} \\
(0.052)\end{array}$ & 1.555 \\
\hline LOG FINANCIAL DEPTH (acquirer) & $\begin{array}{l}0.340^{*} \\
(0.194\end{array}$ & $\begin{array}{l}0.859^{* * * *} \\
(0.084)\end{array}$ & 2.360 & $\begin{array}{l}0.292 \\
(0.250)\end{array}$ & $\begin{array}{l}0.178 \\
(0.112)\end{array}$ & & $\begin{array}{l}0.305 \\
(0.214)\end{array}$ & $\begin{array}{l}0.546^{* * *} \\
(0.103)\end{array}$ & 1.727 \\
\hline $\begin{array}{l}\text { CONCENTRATION - HHI } \\
\text { (acquirer) }\end{array}$ & $\begin{array}{r}-0.174 \\
(0.304)\end{array}$ & $\begin{array}{l}0.072 \\
(0.156)\end{array}$ & & $\begin{array}{l}0.269 \\
(0.350)\end{array}$ & $\begin{array}{r}-0.339^{*} \\
(0.176)\end{array}$ & 0.712 & $\begin{array}{r}-0.744^{*} \\
(0.445)\end{array}$ & $\begin{array}{l}0.067 \\
(0.232)\end{array}$ & \\
\hline \multicolumn{10}{|l|}{ Market sizes - target } \\
\hline $\begin{array}{l}\text { LOG UNEXPLORED MARKET } \\
\text { (target) }\end{array}$ & $\begin{array}{r}-0.044^{* *} \\
(0.020)\end{array}$ & $\begin{array}{c}-0.023^{* * *} \\
(0.006)\end{array}$ & 0.978 & $\begin{array}{r}-0.057 \\
(0.027)\end{array}$ & $\begin{array}{c}-0.056^{* * *} \\
(0.005)\end{array}$ & 0.945 & $\begin{array}{r}-0.038^{*} \\
(0.022)\end{array}$ & $\begin{array}{c}-0.051^{* * *} \\
(0.006)\end{array}$ & 0.950 \\
\hline LOG GDP GROWTH (target) & $\begin{aligned}-0.028 \\
(0.021)\end{aligned}$ & $\begin{aligned}-0.123 \\
(0.083)\end{aligned}$ & & $\begin{aligned}-0.018 \\
(0.024)\end{aligned}$ & $\begin{aligned}-0.058 \\
(0.080)\end{aligned}$ & & $\begin{array}{r}-0.062 \\
(0.044)\end{array}$ & $\begin{array}{r}-0.384^{* *} \\
(0.150)\end{array}$ & 0.685 \\
\hline LOG GDP RESIDUAL (target) & $\begin{array}{l}0.023 \\
(0.015)\end{array}$ & $\begin{array}{l}0.104 \\
(0.075)\end{array}$ & & $\begin{array}{l}0.009 \\
(0.017)\end{array}$ & $\begin{aligned}-0.062 \\
(0.074)\end{aligned}$ & & $\begin{array}{l}0.055^{*} \\
(0.024)\end{array}$ & $\begin{array}{l}0.334^{* * *} \\
(0.116)\end{array}$ & 1.397 \\
\hline \multicolumn{10}{|l|}{ Market sizes - acquirer-target } \\
\hline LOG BILATERAL TRADE & $\begin{array}{l}0.943^{* * * *} \\
(0.182)\end{array}$ & $\begin{array}{l}1.962^{* * *} \\
(0.062)\end{array}$ & 7.115 & $\begin{array}{l}1.006^{* * *} \\
(0.226)\end{array}$ & $\begin{array}{l}0.579^{* * * *} \\
(0.080)\end{array}$ & 1.784 & $\begin{array}{l}0.903^{* * *} \\
(0.217)\end{array}$ & $\begin{array}{l}1.528^{* * *} \\
(0.072)\end{array}$ & 4.608 \\
\hline LOG MIGRANTS & $\begin{array}{l}0.316 * * * \\
(0.086)\end{array}$ & $\begin{array}{l}0.786^{* * * *} \\
(0.031)\end{array}$ & 2.194 & $\begin{array}{l}0.308^{* * * *} \\
(0.113)\end{array}$ & $\begin{array}{l}0.259^{* * * *} \\
(0.042)\end{array}$ & 1.296 & $\begin{array}{l}0.364^{* * *} \\
(0.123)\end{array}$ & $\begin{array}{l}0.969^{* * * *} \\
(0.048)\end{array}$ & 2.635 \\
\hline \multicolumn{10}{|l|}{ Distances } \\
\hline LOG GEOGRAPHIC DISTANCE & $\begin{array}{l}-0.547 \\
(0.403)\end{array}$ & $\begin{array}{c}-2.189^{* * *} \\
(0.183)\end{array}$ & 0.112 & $\begin{aligned}-0.645^{* * *} & (0.514)\end{aligned}$ & $\begin{array}{r}-0.278^{* *} \\
(0.128)\end{array}$ & 0.757 & $\begin{array}{c}-0.296^{* * *} \\
(0.393)\end{array}$ & $\begin{array}{c}-1.983^{* * *} \\
(0.214)\end{array}$ & 0.137 \\
\hline PSYCHIC DISTANCE & $\begin{array}{c}-0.449^{* * * *} \\
(0.115)\end{array}$ & $\begin{array}{c}-0.596^{* * *} \\
(0.025)\end{array}$ & 0.551 & $\begin{array}{l}-0.333 \\
(0.129)^{* *}\end{array}$ & $\begin{array}{c}-0.248^{* * * *} \\
(0.033)\end{array}$ & 0.780 & $\begin{array}{c}-0.407 \\
(0.144)\end{array}$ & $\begin{array}{c}-0.668^{* * *} \\
(0.037)\end{array}$ & 0.513 \\
\hline TIME ZONE & $\begin{array}{r}-0.095^{* *} \\
(0.044)\end{array}$ & $\begin{array}{c}-0.406^{* * * *} \\
(0.014)\end{array}$ & 0.666 & $\begin{array}{c}-0.123 \\
(0.053)\end{array}$ & $\begin{array}{c}-0.271^{* * *} \\
(0.024)\end{array}$ & 0.763 & $\begin{array}{r}-0.104^{* *} \\
(0.052)\end{array}$ & $\begin{array}{c}-0.364^{* * *} \\
(0.020)\end{array}$ & 0.695 \\
\hline \multicolumn{10}{|l|}{ Controls } \\
\hline FINANCIAL OPENNESS (target) & $\begin{array}{l}0.019 \\
(0.023)\end{array}$ & $\begin{array}{r}-0.099 * * \\
(0.045)\end{array}$ & $\begin{array}{l}0.906 \\
(0.050)\end{array}$ & & & & & & \\
\hline $\begin{array}{l}\text { DIFFERENCES IN ECONOMIC } \\
\text { FREEDOM }\end{array}$ & & & & $\begin{array}{r}-11.911 \\
(3.024)\end{array}$ & $\begin{array}{r}-0.849 \\
(5.635)\end{array}$ & & & & \\
\hline COMPETITIVENESS (target) & & & & & & & $\begin{array}{c}-0.002 \\
(0.001)\end{array}$ & $\begin{array}{c}-0.003 \\
(0.009)\end{array}$ & \\
\hline Intercept & $\begin{array}{r}-5.117^{* *} \\
(1.973)\end{array}$ & $\begin{array}{c}-2.869^{* * * *} \\
(0.882)\end{array}$ & & $\begin{array}{c}-7.998 \\
(4.943)\end{array}$ & $\begin{array}{l}7.248^{* * *} \\
(1.760)\end{array}$ & & $\begin{array}{c}-6.747 \\
(2.331)\end{array}$ & $\begin{array}{c}-1.234 \\
(1.426)\end{array}$ & \\
\hline Year effects & Yes & Yes & & Yes & Yes & & Yes & Yes & \\
\hline Country effects & Yes & Yes & & Yes & Yes & & Yes & Yes & \\
\hline Number of observations & 26,478 & 30,228 & & 18,296 & 27,147 & & 11,881 & 12,867 & \\
\hline
\end{tabular}

Standard errors are in parentheses. Significance at the $1 \%, 5 \%$, and $10 \%$ levels is denoted by $* * *, * *$ and $*$, respectively.

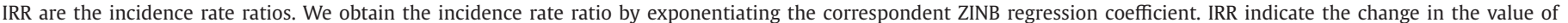
M\&As if a variable changes by one unit. IRR less than 1 implies a decrease in the rate ratio and more than 1 implies an increase in the rate ratio.

The number of observations is less than the number of cases, as incomplete cases for some variables are excluded and some cases are dropped to avoid collinearity.

nificant at the $1 \%$ confidence level, with incidence rate ratios that range from 3.1 to 5.0, the largest effect on M\&As. Focarelli and Pozzolo (2001), in their study of cross-border bank M\&As in OECD countries, also used trade flows to proxy for follow-the-corporatecustomer and obtained similar results. ${ }^{5}$ LOG BILATERAL TRADE has a weaker impact on the probability a country will engage in M\&As (0.937-1.053) than on their value (1.135-1.612). In H1e we hypothesized that domestic banks may also merge and take over banks in countries that host their nationals in order to provide them with retail services. This implies that banks should engage in M\&As in countries where their retail customers are located. This is supported by our findings, since the sign of LOG MIGRANTS, which is the log of the number of home country expatriates living in a target country, is positive and significant at the $1 \%$ confidence level. This variable has the second largest impact with an IRR that ranges from 1.7 to 2.0. Its impact on the value of M\&A deals (coefficient estimates range from 0.507 to 0.696 ) is greater than on their probability (coefficient estimates range from 0.321 to 0.325 ).

The gravity model suggests that the probability and the value of bank M\&As between pairs of countries should be negatively cor-

\footnotetext{
5 Claessens and Van Horen (2013) document that trade and bank internationalization follow similar patterns.
}

related with the distance between them. The most obvious measure of distance is geographic distance. As in other studies (e.g. Buch and DeLong, 2004), we find a negative and statistically significant relationship between our measure of geographic distance, LOG GEOGRAPHIC DISTANCE, and M\&As. LOG GEOGRAPHIC DISTANCE impacts more the value of M\&As than their probability (coefficient estimates are -0.362 to -0.584 for probability of having $M \& A s$ and -0.487 to -0.605 for their value). A one unit increase in LOG GEOGRAPHIC DISTANCE more than halves the value of M\&As (IRR 0.546). While geographic distance is undeniably important, the ability of banks of one country to make and manage acquisitions in another country may also hinge on the similarity of their overall environment. The more dissimilar the environment, the lower the level of information available to managers, and hence the higher the psychic distance between the countries. The higher the psychic distance, the lower the probability to engage in M\&As. As predicted, the coefficient of PSYCHIC DISTANCE, which measures differences in language, religion, education, political systems, and economic development, is negative and significant. Previous studies analyzing the determinants of cross-border bank M\&As (e.g. Buch and DeLong, 2004, 2008) have also found that some components of psychic distance, such as differences in language and legal systems, discouraged M\&As. Our results sug- 
gest that psychic distance has a similar impact as a prerequisite of M\&As as on their value (coefficient estimates for both groups range from -0.297 to -0.506 ). Interestingly, psychic distance has a greater impact than geographic distance on the value of M\&As (the IRRs for PSYCHIC DISTANCE are higher than those for LOG GEOGRAPHIC DISTANCE). We interact our distance variables (LOG GEOGRAPHIC DISTANCE and PSYCHIC DISTANCE) with a time trend to analyze the changes of the effect of distance on the value of M\&As over time. The distance-time trend interaction proxies for an increased degree of market integration over our period of analysis (1981-2010). Our findings suggest that market integration is not a prerequisite for M\&As (the coefficient estimates in panels 1 and 4 are not statistically significant) and affects only the value of M\&As but with a minor impact since the coefficients in panels 2 and 5 are only significant at the $10 \%$ confidence level with an IRR below 1. ${ }^{6}$ These findings differ from those of Brakman et al. (2014), which might be due to a different sample - we analyze banking and Brakman et al. (2014) conduct a cross-industry analysis and a more recent period of analysis - 1981-2010 as compared to 1896-2005. Time zone differences should also increase communication difficulties between acquirer and targets, and hence discourage M\&As. As predicted by H2c, the coefficient of TIME ZONE, the absolute number of time zones between two countries, is significantly negative (at the 5\%-10\% confidence level for the probability of M\&As and at $1 \%$ for their value). This is consistent with Stein and Daude (2007), who found that differences in time zones had a significant negative effect on trade and foreign direct investment. One would also expect the number of M\&As to be lower in target countries that restrict foreign investment in banking. As predicted by H2d, REGULATORY RESTRICTIONS, our variable which measures the extent to which foreign banks are allowed to enter the target market, has a negative and statistically significant impact on the value of M\&A deals with an IRR at 0.8.

Surprisingly our variables that measure target market opportunities are not significant or take the wrong sign. Our measure of the market potential of target countries, LOG UNEXPLORED MARKET, which is the difference between the financial depth of the target market and that of the United Sates, is significant but takes a negative sign, which is contrary to our expectations. We had thought that banks would be attracted to growing markets, but our measure of the rate of growth of the target market, LOG GDP GROWTH, is significantly negative. Lastly, more stable target countries do not seem to attract more cross-border acquisitions, as the coefficient of LOG GDP RESIDUAL is statistically insignificant, except in Panel 1 for the probability of M\&As.

\subsection{Robustness tests}

We perform five robustness tests to control for several institutional differences between acquirer and target countries (see also Berger et al., 2004). In these tests we assess the influence of variables that have been found significant in past studies and have theoretical justifications for potentially influencing the dependent variable (Okawa and van Wincoop, 2012). First, in Table 4, panels 1-3 (probability and value of deals), we add a control for de jure FINANCIAL OPENNESS, since M\&As rely on international capi-

\footnotetext{
${ }^{6}$ Brambor et al. (2006) suggest that interaction terms should be included in the regressions when they pertain to conditional hypotheses. Our hypotheses that the amount of M\&As by banks of one country into another are affected by geographical and psychic distances are not conditional on TIME TREND. As TIME TREND is not a modifying variable we do not enter it in the runs and so avoid collinearity with time fixed effects. We enter TIME TREND to explore the possibility that increased integration might have reduced the impact of geographical distance and psychic distance on M\&As. As it happens, the statistical and economical significance of GEOGRAPHIC DISTANCE and PSYCHIC DISTANCE are not considerably affected when we enter the interaction of these variables with TIME TREND.
}

tal flows (Brakman et al., 2014). This variable is measured by the Chinn-Ito index initially introduced by Chinn and Ito (2006) and now updated as of the end of 2013 to capture a country's degree of capital account openness. FINANCIAL OPENNESS has no statistically significant impact on the probability of making an M\&A, suggesting that it is not a prerequisite for M\&As, but is significant at the 5\% confidence level for the value of M\&As. However, the IRR for this variable (0.906) is relatively low. Second, in Panels 4-6, we add a control for DIFFERENCES IN ECONOMIC FREEDOM between target and acquirer countries, as calculated by the Heritage Foundation. This variable measures differences between acquirer and target countries in freedom of doing business, level of economic openness, regulatory efficiency, and rule of law. Our results are confirmed. Third, in Panels 7-9, we control for the degree of COMPETITIVENESS of the target country using the competitiveness score assigned by the IMD World Competitiveness Center. Again, this does not change our results. Fourth, in unreported findings, we exclude the countries that are responsible for the largest number and value of deals. i.e. the U.S., U.K. and France. Our previous results are again confirmed. Fifth, we divide the sample in four sub-periods that reflect the four merger waves suggested in Fig. 1 - 1981-1991, 1992-2000, 2001-2004, and 2005-2010. We are interested in changes over time of $M \& A s$ determinants. Since economic and financial integration has been increasing over time, we expect the distance variables to become less important. Our results, available upon request, suggest that increased economic integration has markedly reduced the effect of both geographic and psychic distances from 1992 onwards.

\section{Conclusions}

The large increase in cross-border M\&As in banking over the past three decades and the recent contraction in international banking networks have attracted considerable scholarly attention (Minoiu and Reyes, 2013). Our paper focuses on country level determinants of M\&As in banking. In contrast to past studies that have looked at a single or a small group of acquiring and target countries, we collected data on the M\&As made by banks in 89 acquiring countries into 118 target countries over a 30 year period (1981-2010). We use a gravity framework to predict the determinants of the probability of country pairs having bank M\&As and of their value. Gravity models have been extensively used to model international trade flows (e.g. Anderson, 2011) and more recently foreign direct investments (e.g. Hejazi, 2007), including those in banking (Claessens and Van Horen, 2014b).

We test a number of hypotheses on the factors that motivate and restrain cross-border M\&As. Some of them receive empirical support. Consistent with transaction costs and internalization theories (e.g. Hennart, 1982), we find that banks make cross-border M\&As to exploit their firm-specific advantages. They also establish a foreign presence through the acquisition of foreign banks to maintain relationships with domestic market customers present in the target country, as failure to serve them in that country may lead their customers to switch to local banks and to ultimately threaten the domestic banking relationship (Clare et al., 2013). We also find support for the novel hypothesis that banks make foreign acquisitions to serve their domestic retail customers who have emigrated to foreign countries. We hypothesize that banks based in countries where banking is highly concentrated make foreign acquisitions to escape limitations to domestic growth, but this novel hypothesis does not receive empirical support. We introduce a new way of measuring the degree to which target markets are underserved by the existing banking system, but this measure does not perform well. Another unexpected finding is that banks do not seem to target potential high growth countries. 
Turning to the restraining factors, we find, alongside many extant studies, that M\&As are deterred by geographical distance. While the literature has also used non-geographic measures of distance, such as dummies for common language and legal tradition, we use a more comprehensive measure of psychic distance (which for example acknowledges that in some countries a substantial part of the population may speak a language common with other countries) and find it to be a significant deterrent to foreign banking M\&As. We also look at the impact of time zone differences and find it has a similar effect. Lastly we control with a time-variant measure of target country regulatory barriers to bank entry.

Our paper suggests avenues for further research. First, for reasons of data availability, we focus on M\&As, which is the most common form of foreign market entry in banking (Eppendorfer, 2002). Researchers may want to test whether our model also applies to foreign entry through greenfields. Researchers might also want to focus at what makes countries attractive to foreign bank entrants and improve on our measure of under-served markets. The impact of domestic banking structure on cross-border M\&As would also seem to deserve further study. Lastly, while much of the extant literature has focused on new entries, the recent banking crisis might offer interesting opportunities in studying banking exits. Which factors explain disinvestments from foreign markets, and are they the same as those that have been found to determine entry?

\section{Acknowledgments}

The authors acknowledge financial and administrative support from FCT (PTDC/EGE-ECO/114977/2009) and Instituto Universitário de Lisboa (ISCTE-IUL). We would like to thank Alberto Pozzolo, Andrew Clare, Bob de Young, Jay Dahya, Adrian Tschoegl, and seminar participants at the 6th IFABS Lisbon 2014 Conference on 'Alternative Futures for Global Banking: Competition, Regulation and Reform' for their comments and suggestions.

\section{References}

Amel, D., Barnes, C., Panetta, F., Salleo, C., 2004. Consolidation and efficiency in the financial sector: a review of the international evidence. Journal of Banking and Finance 28 (1), 2493-2519.

Anderson, J.E., 1979. A theoretical foundation for the gravity equation. American Economic Review 69 (1), 106-115.

Anderson, J.E., Wincoop, E.van, 2003. Gravity with gravitas: a solution to the border puzzle. American Economic Review 93 (1), 170-192.

Anderson, J.E., 2011. The gravity model. Annual Review of Economics 3 (1), 133-160.

Barth, R.J., Caprio, G., Levine, R., 2013. Bank regulation and supervision in 180 countries from 1999 to 2011. Journal of Financial Economic Policy 5 (2), 11-219.

Beck, T., Demirguc-Kunt, A., Levine, R., 2001. The Financial Structure Database. In: Demirguc-Kunt, A., Levine, R. (Eds.), Financial Structure and Economic Growth: A Cross-country Comparison of Banks, Markets, and Development. MIT Press, Cambridge, pp. 17-80.

Berger, A.N., Hunter, W.C., Humphrey, D.B., 1993. The efficiency of financial institutions: a review and preview of research, past, present and future. Journal of Banking and Finance 17, 221-250.

Berger, A.N, Bonime, S.D., Goldberg, L.G., White, L.J., 1999. The dynamics of market entry: the effects of mergers and acquisitions on entry in the banking industry. Journal of Business 77 (4), 797-834.

Berger, A.N., Buch, C.M., DeLong, G., DeYoung, R., 2004. Exporting financial institutions management via foreign direct investment mergers and acquisitions. Journal of International Money \& Finance 23 (3), 333-366.

Bergstresser, D., 2008. The retail market for structured notes: issuance patterns and performance. Harvard Business School, pp. 1995-2008 Working Paper.

Brakman, S., Garita, Garretsen, G., van Marrewijk, H., 2014. Economic and Financial Integration and the Rise of Cross-border M\&As. In: van Bergeijk, P., Brakman, S. (Eds.), The Gravity Model in International Trade. Cambridge University Press, Cambridge Chapter 11

Brambor, T., Clark, W.R., Golder, M., 2006. Understanding interaction models: improving empirical analyses. Political Analysis 14 (1), 63-82.

Brüggemann, B., Kleinert, J., Prieto, E., 2012. A gravity equation for bank loans. Universities of Graz and Tuebingen, Mimeo.

Buch, C.M., DeLong, G.L., 2004. Cross-border bank mergers: what lures the rare animal? Journal of Banking and Finance 28 (9), 2077-2102.

Buch, C.M., Lipponer, A., 2007. FDI versus exports: evidence from German banks. Journal of Banking and Finance 31 (3), 805-826.
Buch, C.M., DeLong, G.L., 2008. Banking globalization: International consolidation and mergers in banking. Discussion paper no. 38, Institut für Angewandte Wirtschaftsforschung (IAW).

Buch, C.M., Neugebauer, K., Schröder, C., 2013. Changing forces of gravity: How the crisis affected international banking. Discussion paper no. 48, Deutsche Bundesbank

Buch, C.M., Kleinert, J., Toubal, F., 2014. The distance puzzle: on the interpretation of the distance coefficient in gravity equations. Economic Letters 83 (3), 293-298.

Caiazza, S., Pozzolo, A.F., Trovato, G., 2011. Are domestic and cross-border M\&A different? Cross-country evidence from the banking sector. Working paper no. 52, Money \& Finance Research (MoFIR).

Caiazza, S., Clare, A., Pozzolo, A.F., 2012. What do foreigners want? Evidence from targets in bank cross-border M\&A. Journal of Banking \& Finance 36 (9) 2641-2659.

Cameron, A.C., Trivedi, P.K., 2009. Microeconometrics Using Stata. Stata Press, United States.

Chinn, M.D., Ito, H., 2006. What matters for financial development? Capital controls, institutions, and interactions. Journal of Development Economics 81 (1) 163-192.

Claessens, S., Van Horen, N., 2013. Impact of foreign banks. DNB Working paper no. $370 / 2013$.

Claessens, S., Van Horen, N., 2014a. Foreign banks: trends and impact. Journal of Money, Credit and Banking 46 (1), 145-170.

Claessens, S., Van Horen, N., 2014b. Location decisions of foreign banks and competitor remoteness. Journal of Money, Credit and Banking 46 (1), 295-326.

Clare, A., Gulamhussen, M.A., Pinheiro, C., 2012. What factors cause foreign banks to stay in London? Journal of International Money and Finance 32 (4), 739-761.

Clare, A., Gulamhussen, M.A., Pinheiro, C., 2013. Multimarket contact and the cross-border expansion of commercial banks. Cass Business School Working paper no. $01 / 13$.

Correa, R., 2009. Cross-border bank acquisitions: is there a performance effect? Journal of Financial Services Research 36 (2-3), 169-197.

Cornett, M.M., Hovakimian, G., Palia, D., Tehranian, H., 2003. The impact of the manager-shareholder conflict on acquiring bank returns. Journal of Banking and Finance 27 (1), 103-131.

Cornett, M.M., McNutt, J.J., Tehranian, H., 2006. Performance changes around bank mergers: revenue enhancements versus cost reductions. Journal of Money, Credit and Banking 38 (4), 1013-1050.

Craig, S., Hardee, P., 2007. The impact of bank consolidation on small business credit availability. Journal of Banking and Finance 31 (4), 1237-1263.

Craig, B.R., Dinger, V., 2009. Bank mergers and the dynamics of deposit interest rates. Journal of Financial Services Research 36 (2-3), 111-133.

DeLong, G., 2001. Stockholder gains from focusing versus diversifying bank mergers Journal of Financial Economics 59 (2), 221-252.

DeLong, G., 2003. Does long-term performance of mergers match market expectations? Evidence from the US banking industry. Financial Management 32 (2) $5-25$.

DeYoung, R., Douglas, E., Molyneux, P., 2009. Mergers and acquisitions of financial institutions: a review of the post-2000 literature. Journal of Financial Services Research 36 (2-3), 87-110.

Ellis, P., 2008. Does psychic distance moderate the market size-entry sequence relationship? Journal of International Business Studies 39 (3), 351-369.

Eppendorfer, C., Beckman, R., Neimke, M., 2002. Market access strategies in the EU banking sector - obstacles and benefits towards an integrated European retail market. IEW Diskussionsbeitrag. Ruhr-University Bochum.

Esperanca, J.P., Gulamhussen, M.A., 2001. (Re)Testing the 'follow the customer' hypothesis in multinational bank expansion. Journal of Multinational Financial Management 11 (3), 281-293.

Focarelli, D., Pozzolo, A.F., 2001. The patterns of cross-border bank mergers and shareholdings in OECD countries. Journal of Banking and Finance 25 (12), 2305-2337.

Focarelli, D., Pozzolo, A.F., 2006. Where do banks expand abroad? An empirical analysis. Journal of Business 78 (6), 2435-2464.

Focarelli, D., Pozzolo, A.F., 2008. Cross-border M\&AS in the financial sector: is banking different from insurance? Journal of Banking and Finance 32 (1), 15-29.

Garmaise, M.J., Moskowitz, T.J., 2006. Bank mergers crime: the real and social effects of credit market competition. Journal of Finance 61 (2), 495-538.

Giovanni, J., 2005. What drives capital flows? The case of cross-border M\&A activity and financial deepening. Journal of International Economics 65 (1) 127-149.

Guillen, M., Tschoegl, A., 2000. The internationalization of retail banking: the case of Spanish banks in Latin America. Transnational Corporations 9 (3), 63-97.

Helpman, E., Melitz, E.M., Rubenstein, Y., 2007. Estimating trade flows: trading partners and trading volumes. Quarterly Journal of Economics 123 (2), 441-487.

Heckman, J., 1979. Sample selection bias as a specification error. Econometrica 47 (1), 153-161.

Hennart, J.-F., 1982. A Theory of Multinational Enterprise. University of Michigan Press, Ann Arbor.

Hejazi, W., 2007. Reconsidering the concentration of US MNE activity: is it global, regional, or national? Management International Review 47, 5-27.

Hughes, J.P., Mester, L.J., 2011. Who said large banks don't experience scale economies? Evidence from a risk-return-driven cost function. Journal of Financial Intermediation 22 (4), 559-585.

Kogut, B., 1991. Joint ventures and the option to acquire. Management Science 37 (1), 19-33. 
Lambert, D., 1992. Zero-inflated Poisson regression, with an application to defects in manufacturing. Technometrics 34 (1), 1-14.

Leamer, E., Levinsohn, J., 1995. International trade theory: The evidence. In: Grossman, G., Rogoff, K. (Eds.). Handbook of International Economics, Vol. 3. Elsevier, Amsterdam.

Martin, P., Rey, H., 2004. Financial supermarkets: size matters for asset trade. Journal of International Economics 64 (2), 355-361.

Melitz, M.J., 2003. The impact of trade on intra-industry reallocations and aggregate industry productivity. Econometrica 71 (6), 1695-1725.

Minoiu, C., Reyes, J.A., 2013. A network analysis of global banking: 1978-2010. Journal of Financial Stability 9, 168-184.

OECD, 1993. Migration and International Co-operation: Challenges for OECD Countries. OECD/GD 93 (57)

O'Grady, S., Lane, H.W., 1996. The psychic distance paradox. Journal of International Business Studies 27 (2), 309-333.

Okawa, T., van Wincoop, E., 2012. Gravity in international finance. Journal of International Economics 87 (2), 205-215.

Panetta, F., Schivardi, F., Shum, M., 2009. Do mergers improve information? Evidence from the loan market. Journal of Money, Credit and Banking 41 (4), 673-709.

Park, K., Pennacchi, G., 2009. Harming depositors and helping borrowers: the disparate impact of bank consolidation. Review of Financial Studies 22 (1), 1-40.

Pellerin, A., 2009. Les Portugais à Paris au Fil des Siècles et des Arrondissements. Chandeigne, Paris.

Ratha, D., Shaw, W., 2007. South-South migration and remittances. World Bank Working paper no. 102
Santos-Silva, J., Tenreyro, S., 2006. The log of gravity. The Review of Economics and Statistics 88 (4), 641-658.

Stein, E., Daude, C., 2007. Longitude matters: time zones and the location of foreign direct investment. Journal of International Economics 71, 96-112.

Tinbergen, J., 1962. Shaping the World Economy. The Twentieth Century Fund, New York.

Tschoegl, A., 1987. International retail banking as a strategy: an assessment. Journal of International Business Studies 19 (2), 67-88.

Tschoegl, A., 2002. The international expansion of Singapore's largest banks. Journal of Asian Business 18 (1), 1-35.

Tschoegl, A., 2004. Who owns the major US subsidiaries of foreign banks: a note. Journal of International Financial Markets, Institutions and Money 14 (3), 255-266.

Tschoegl, A., 2005. The Californian subsidiaries of Japanese banks: a genealogical history. Journal of Asian Business 20 (2), 59-82.

Vrontis, D., Sharp, I., 2003. The strategic positioning of Coca-Cola in their global marketing operation. The Marketing Review 3 (3), 289-309.

Williams, B., 1997. Positive theories of multinational banking: eclectic theory versus internalization theory. Journal of Economic Surveys 11 (1), 71-100.

Wooldridge, J.M., 2010. Econometric Analysis of Cross Section and Panel Data. In: Barth, J.R., Caprio, Jr., G., Levine, R. (Eds.), World Bank Surveys on Bank Regulation by. MIT, United States 2012. Available at www.worldbank.org.

Zhu, L., Yang, J., 2008. The role of psychic distance in contagion: a gravity model for contagious financial crisis. Journal of Behavioral Finance 9 (4), 209-223. 